\title{
An experimental design to study colonic fibre fermentation in the rat: the duration of feeding
}

\author{
By DEBORAH J. WALTER, M. A. EASTWOOD* AND W. G. BRYDON \\ Wolfson Laboratories, Gastrointestinal Unit, Department of Medicine, \\ University of Edinburgh, Western General Hospital, Edinburgh EH4 $2 \mathrm{XU}$ \\ AND R. A. ELTON \\ Medical Computing and Statistics Unit, Faculty of Medicine, \\ University of Edinburgh, Teviot Place, Edinburgh
}

(Received 25 July 1985 - Accepted 8 November 1985)

\begin{abstract}
1. The time-course of metabolic adaptation by rats to diets containing either wheat bran or gum arabic was studied during a 12-week period.

2. Stool weight was increased with wheat bran but not with gum arabic, and had stabilized after 4 weeks.

3. Bacterial mass as measured by diaminopimelic acid content had stabilized by week 4 . Bacterial mass increased on feeding gum arabic but was unchanged with wheat bran.

4. There was increased caecal short-chain fatty acid, hydrogen and methane production with gum arabic but not with wheat bran. The change in caecal metabolic activity was slow to stabilize (8-12 weeks at least).

5. The faecal excretion of bile acids increased twofold with the wheat-bran-supplemented diet compared with the gum-arabic-supplemented and unsupplemented diets. Relatively greater amounts of muricholic acids were present in the caeca and faeces of gum-arabic-fed rats compared with the other groups.
\end{abstract}

Fibre is known to have a variety of functions and a series of metabolic fates along the gastrointestinal tract (Royal College of Physicians, 1980). For example, fibre is fermented in the caecum both in man and the rat (Cummings et al. 1978; McKay \& Eastwood, 1983). The products of such fermentation are short-chain fatty acids (SCFA), hydrogen, methane and carbon dioxide (Rodkey et al. 1972; McNeil et al. 1977; Thomsen et al. 1981). The effect of duration of feeding a fibre-supplemented diet on the metabolism of dietary fibre in the colon has not been formally studied. Most trials have spanned 3-5 weeks (Janowitz \& Grossman, 1949; Goldin \& Gorbach, 1976; Younoszai et al. 1978; Mallett et al. 1984a,b) but longer trials have been reported (Leegwater et al. 1974; Edozien \& Switzer, 1978). Elsenhans et al. (1981), in their studies of the effects of long-term feeding of carbohydrategelling agents on the anatomy of the rat gastrointestinal tract, considered a period of $52 \mathrm{~d}$ to be optimal. McLean-Ross et al. (1984) monitored the excretion of $\mathrm{H}_{2}$ and $\mathrm{CH}_{4}$ by rats given gum arabic during a period of 0,14 and $28 \mathrm{~d}$ with either a low- or high-fibre diet. They found that diet and the addition of fibre was more important than the duration of feeding.

The purpose of the present study was to evaluate the effect of novel fibres on colonic contents and faeces, thereby reducing the reliance for, and necessity of, time-consuming and laborious human trials (Eastwood et al. 1983). This required inter alia identification of an acceptable minimum time-period for a wide variety of dietary-fibre-supplementation studies. A fibre-free diet was chosen to which was added $100 \mathrm{~g}$ gum arabic/kg or $100 \mathrm{~g}$ coarse wheat bran $/ \mathrm{kg}$ dry weight. These fibres form a useful contrast, and have been studied in human subjects (Eastwood et al. 1973; McLean-Ross et al. 1983). Gum arabic is a fermentable fibre source while wheat bran is relatively, although not entirely, unfermented in the colon.

The effect of the supplemental fibres on caecal metabolism and faecal output were * For reprints. 
Table 1. Ingredients and composition of unsupplemented fibre-free diet $(\mathrm{g} / \mathrm{kg})$ and composition of Canadian Red Spring Wheat bran

\begin{tabular}{lclc}
\hline \hline Ingredients & & Composition & \\
\hline Soya-bean concentrate & 200 & Fat & 30 \\
Soya-bean oil & 30 & Protein & 130 \\
Maize flour & 720 & Carbohydrate & 830 \\
Vitamins and minerals & 50 & Fibre & 8 \\
Composition of Canadian & Red Spring & Wheat bran $\dagger$ (coarse particle size $)(\mathrm{g} / \mathrm{kg})$ \\
Starch & 175 & Cellulose & 97 \\
Pectin & $4 \cdot 4$ & Lignin & $4 \cdot 7$ \\
Hemiceilulose & 228 & Protein & 148 \\
& & Fat & 64 \\
\hline
\end{tabular}

* Comprised $(/ \mathrm{kg}$ diet $)$ : retinol $1500 \mu \mathrm{g}$, cholecalciferol $25 \mu \mathrm{g}$, vitamin E $50 \mathrm{mg}$, thiamin $5 \mathrm{mg}$, riboflavin $5 \mathrm{mg}$, vitamin $\mathrm{B}_{6} 5 \mathrm{mg}$, vitamin $\mathrm{B}_{12} 5 \mu \mathrm{g}$, nicotinic acid $10 \mathrm{mg}$, pantothenic acid $10 \mathrm{mg}$, folic acid $0.5 \mathrm{mg}$, biotin $20 \mu \mathrm{g}$, choline $200 \mathrm{mg}$, vitamin $\mathrm{K} 10 \mathrm{mg}$, lysine $1 \mathrm{~g}$, methionine $1 \mathrm{~g}$, iron $50 \mathrm{mg}$, cobalt $0.5 \mathrm{mg}$, manganese $25 \mathrm{mg}$, copper $5 \mathrm{mg}$, zinc $10 \mathrm{mg}$, iodine $0.5 \mathrm{mg}$, magnesium $100 \mathrm{mg}$, sodium chloride $5 \mathrm{~g}$, calcium $6 \mathrm{~g}$, phosphorus $4 \mathrm{~g}$.

+ Water-holding capacity $8.5 \mathrm{~g}$ water $/ \mathrm{g}$ fibre.

evaluated by measuring caecal and faecal weights, SCFA, expired $\mathrm{H}_{2}$ and $\mathrm{CH}_{4}$ and bile acids at 4-, 8- and 12-week intervals. Diaminopimelic acid (DAPA) was measured as an index of bacterial mass (Czerkawski, 1974) and was measured in caecal and faecal contents.

The chosen measurements were considered to be the best available indicators of dietary fibre metabolism. Stool weight was recorded because this is the most-used indicator of dietary fibre metabolism in the human colon. The caecal contents were studied because of the role of the caecum as a fermenter and the importance of bacterial mass. $\mathrm{H}_{2}, \mathrm{CH}_{4}$ and SCFA were chosen as further indicators of bacterial metabolism. Bile acids, important constituents of the intestinal contents, were also measured to study the influence of fibre along the gastrointestinal tract.

\section{MATERIALS AND METHODS}

\section{Animals}

Forty-five male adult rats, of the Wistar strain, mean live weight 419 (SE 6) g, were caged in nine groups of five. Food, presented in stainless-steel bowls, and water were available ad lib.

\section{Diets}

The diet chosen was composed of protein, fat and carbohydrate of plant origin (diet FF; digestible energy (DE) $13.9 \mathrm{MJ} / \mathrm{kg}$, gross energy (GE) $15.94 \mathrm{MJ} / \mathrm{kg}$, fibre $8 \mathrm{~g} / \mathrm{kg}$ ) (Van Soest, 1966) supplied by Special Diets Services, Witham, Essex (Table 1). To this was added $100 \mathrm{~g} / \mathrm{kg}$ dry weight of either gum arabic (confectionary grade; Rowntree McIntosh Ltd, York; diet FG) or Canadian Red Spring Wheat bran (coarse) of known fibre content and water holding capacity (Eastwood et al. 1983) supplied by Chancelot Mills, Edinburgh (diet FB). Fifteen rats were allocated to each of these three diets. Food residues were weighed daily for estimation of food intake.

\section{Faeces and gas collection}

Before being killed rats were placed in individual, broad-spaced-gridded anti-coprophagy cages for collection of faeces for $3 \mathrm{~d}$. Faeces were then weighed, $\mathrm{pH}$ adjusted when necessary to $\mathrm{pH} 8$, frozen $\left(-20^{\circ}\right)$ and subsequently freeze-dried and reweighed. 
$\mathrm{H}_{2}$ and $\mathrm{CH}_{4}$ production were estimated by placing a single rat of known weight in an air-tight box $(300 \times 200 \times 200 \mathrm{~mm}, 12$ litre volume) for $15 \mathrm{~min}$. At the end of this time, a $50 \mathrm{ml}$ sample of air-space gas was taken and analysed by gas-solid chromatography (Tadesse et al. 1979) using a Pye Series 104 chromatograph.

\section{Killing procedure}

Each group of fifteen rats was given the diet for 4,8 or 12 weeks, five rats being killed every 4 weeks following diethyl ether anaesthesia at 08.00-09.00 hours. All rats were weighed every $7 \mathrm{~d}$ at the same time each week. After death, the livers were removed, washed, blotted dry, weighed and frozen (at $-20^{\circ}$ ). The caecum was identified, removed, blotted dry and weighed. The caecal contents were removed and the remaining empty caecal sac blotted dry and weighed. Caecal contents were weighed, frozen (at $-20^{\circ}$ ) and subsequently freeze-dried and reweighed.

\section{Chemical and statistical analysis}

All analytical procedures were applied to freeze-dried material. SCFA (acetic, propionic, butyric, valeric and isovaleric acids) were measured by the method of Spiller et al. (1980). Bile acids were analysed using a pooled sample of either faecal or caecal dry matter, from each group of five rats (Brydon et al. 1979). DAPA was estimated using the method of Czerkawski (1974).

All results quoted are mean values with their estimated standard errors of means. Results were compared using a two-factor analysis of variance with replication. Probability plots of residuals showed that the assumption of a normal distribution was approximately satisfied for all the variables except $\mathrm{H}_{2}$ and $\mathrm{CH}_{4}$ which showed some positive skewness. This was corrected for these two variables by a square-root transformation. Analysis of variance repeated on the transformed data gave similar qualitative conclusions to those for the original data.

\section{RESULTS}

Animals on the three diets gained weight steadily over the 12-week period. Initial mean live weights (g) were 440 (SE 10), 395 (SE 12), 420 (SE 52) for the groups at 4, 8 and 12 weeks respectively. Mean live weights (g) at the end of these three time periods were 492 (SE 11), 477 (SE 14), 530 (SE 16) respectively. Diet had no significant influence on weight gain. Of the forty-five rats only one had to be killed $3 \mathrm{~d}$ early due to overlong teeth and subsequent gum infection. As a consequence teeth were checked for length and clipped every 2 weeks. One rat from the 12-week diet-FB group was found, at post mortem, to have hydronephrosis with numerous ureteric and bladder stones. Neither of these conditions appeared to have affected any measurements except live weight of the rat.

Table 2 summarizes the two-factor analysis of variance for the various measurements for diet and period of study.

Faecal wet weight was not recorded as stools dried in a variable manner. Fig. 1 shows that by 4 weeks, adding $100 \mathrm{~g}$ coarse wheat bran $/ \mathrm{kg}$ to the diet increased dry faecal weight by approximately $65 \%$ and $40 \%$ relative to diets FF and FG $(P<0.01)$ respectively. Faecal dry weight showed no significant interaction between diet and time-period, nor was there a significant time-period effect (Table 2).

Diet FG increased caecal sac wet weight $(P<0.01)$ relative to diets FB and FF which were not significantly different from each other (Fig. 2). Caecal sac wet weight showed no significant interaction between diet and time-period, nor was there a significant time-period effect (Table 2).

The presence of $100 \mathrm{~g}$ gum arabic/ $\mathrm{kg}$ stimulated an increase in caecal-contents dry weight (Fig. 3) which was significantly $(P<0.01)$ greater than that of diets FF and FB throughout 
Table 2. A summary table of the $\mathrm{F}$ statistics

\begin{tabular}{|c|c|c|c|}
\hline Variable & Diet & Time-period & Interaction \\
\hline \multicolumn{4}{|l|}{ Live-wt (g) } \\
\hline Initial & $1.36 \mathrm{NS}$ & $3.87^{*}$ & $1 \cdot 18 \mathrm{NS}$ \\
\hline Final & $3.05 \mathrm{NS}$ & $4.35^{*}$ & $0.24 \mathrm{NS}$ \\
\hline \multicolumn{4}{|l|}{ Stool dry wt } \\
\hline$(\mathrm{g})$ & $26.56 * *$ & $2 \cdot 11 \mathrm{NS}$ & $1 \cdot 44 \mathrm{NS}$ \\
\hline$(\mathrm{g} / \mathrm{kg})$ & $33.59 * *$ & $0.38 \mathrm{NS}$ & $1.67 \mathrm{NS}$ \\
\hline \multicolumn{4}{|l|}{ Caecal sac wet wt } \\
\hline$(\mathrm{g})$ & $37.5 * *$ & $2.50 \mathrm{NS}$ & $1.50 \mathrm{NS}$ \\
\hline$(\mathrm{g} / \mathrm{kg})$ & $64 \cdot 0^{* *}$ & $8 \cdot 67^{* * *}$ & $1.00 \mathrm{NS}$ \\
\hline \multicolumn{4}{|l|}{ Caecal contents (dry) } \\
\hline$(\mathrm{g})$ & $87 \cdot 6^{* *}$ & $8 \cdot 2^{* *}$ & $6 \cdot 2^{* *}$ \\
\hline$(\mathrm{g} / \mathrm{kg})$ & $99 \cdot 3 * *$ & $11 \cdot 15^{* *}$ & $6.75^{* *}$ \\
\hline Caecal DAPA $(\mu \mathrm{mol})$ & $98 \cdot 2 * *$ & $0.82 \mathrm{NS}$ & $0.08 \mathrm{NS}$ \\
\hline Faecal DAPA $(\mu \mathrm{mol} / \mathrm{d})$ & $32 \cdot 4^{* *}$ & $3.89^{*}$ & $0.74 \mathrm{NS}$ \\
\hline Hydrogen $(\mathrm{ml} / \mathrm{h}$ per $\mathrm{kg})$ & $0.06 \mathrm{NS}$ & $6 \cdot 3^{* *}$ & $1.88 \mathrm{NS}$ \\
\hline Methane $(\mathrm{ml} / \mathrm{h}$ per $\mathrm{kg})$ & $12 \cdot 7^{* *}$ & $1.64 \mathrm{NS}$ & $1.29 \mathrm{NS}$ \\
\hline \multicolumn{4}{|l|}{ SCFA } \\
\hline Caecal $(\mu \mathrm{mol})$ & $61 \cdot 7 * *$ & $1.66 \mathrm{NS}$ & $0.67 \mathrm{NS}$ \\
\hline Faecal $(\mu \mathrm{mol} / \mathrm{d})$ & $11 \cdot 4^{* *}$ & $9 \cdot 55^{* *}$ & $2.07 \mathrm{NS}$ \\
\hline Caecal $(\mu \mathrm{mol} / \mathrm{g})$ & $7 \cdot 33^{* *}$ & $0 \cdot 86 \mathrm{NS}$ & $7.93^{* *}$ \\
\hline Faecal $(\mu \mathrm{mol} / \mathrm{g})$ & $17 \cdot 44 * *$ & $22 \cdot 5^{* *}$ & $12,7 * *$ \\
\hline \multicolumn{4}{|l|}{ Acetate } \\
\hline Caecal $(\mathrm{mmol} / \mathrm{mol})$ & $20 \cdot 3 * *$ & $2 \cdot 49 \mathrm{NS}$ & $0 \cdot 28 \mathrm{NS}$ \\
\hline Faecal $(\mathrm{mmol} / \mathrm{mol})$ & $10 \cdot 3^{* *}$ & $0.15 \mathrm{NS}$ & $2.59 \mathrm{NS}$ \\
\hline \multicolumn{4}{|l|}{ Propionate } \\
\hline Caecal $(\mathrm{mmol} / \mathrm{mol})$ & $1 \cdot 07 \mathrm{NS}$ & $10 \cdot 3^{* *}$ & $1.09 \mathrm{NS}$ \\
\hline Faecal $(\mathrm{mmol} / \mathrm{mol})$ & $28 \cdot 2 * *$ & $0.42 \mathrm{NS}$ & $3 \cdot 12 \mathrm{NS}$ \\
\hline \multicolumn{4}{|l|}{ Butyrate } \\
\hline Caecal $(\mathrm{mmol} / \mathrm{mol})$ & $44 \cdot 5^{* *}$ & $0.05 \mathrm{NS}$ & $0.78 \mathrm{NS}$ \\
\hline Faecal $(\mathrm{mmol} / \mathrm{mol})$ & $2 \cdot 82 \mathrm{NS}$ & $0.63 \mathrm{NS}$ & $0.84 \mathrm{NS}$ \\
\hline
\end{tabular}

DAPA, 2,6-diaminopimelic acid; NS, not significant.

${ }^{*} P<0.05 ; * * P<0.01$.

the 4-, 8- and 12-week periods. Compared with animals on diet FF, caecal-contents dry weight was significantly heavier $(P<0 \cdot 01)$ at 4 weeks on diet FG. There was no significant difference between diet FG at 8 weeks and diet FG at 12 weeks. On diets FF and FB (Table 2) there was no significant difference between any of the six groups.

There was a highly significant interaction between diet and time-period for dry caecal contents as shown in Table 2. Fig. 3 shows that the values obtained with diet FG were much greater at 4 weeks but the difference diminished steadily with time.

The addition of gum arabic significantly $(P<0.01)$ increased total faecal DAPA relative to FB and FF diets respectively (Fig. 4(a)). A significant effect of time $(P<0.05)$ was shown in all groups between 4 weeks and 8 weeks but not between 12 weeks and either 4 weeks or 8 weeks. Gum arabic significantly increased total caecal DAPA compared with diets FF and FB which remained unchanged after 4 weeks (Fig. 4(b)). Caecal DAPA showed no significant interaction between diet and time-period, nor was there a significant time-period effect (Table 2).

$\mathrm{H}_{2}$ was detected in all rats but there was no significant effect of diet on output. $\mathrm{H}_{2}$ production in all groups, diet FF-, FG- and FB-fed rats, diminished $(P<0.01)$ over the 12-week period of study (Tables 2 and 3). $\mathrm{H}_{2}$ showed no significant interaction between diet and time-period, nor was there a significant time-period effect (Table 2). 


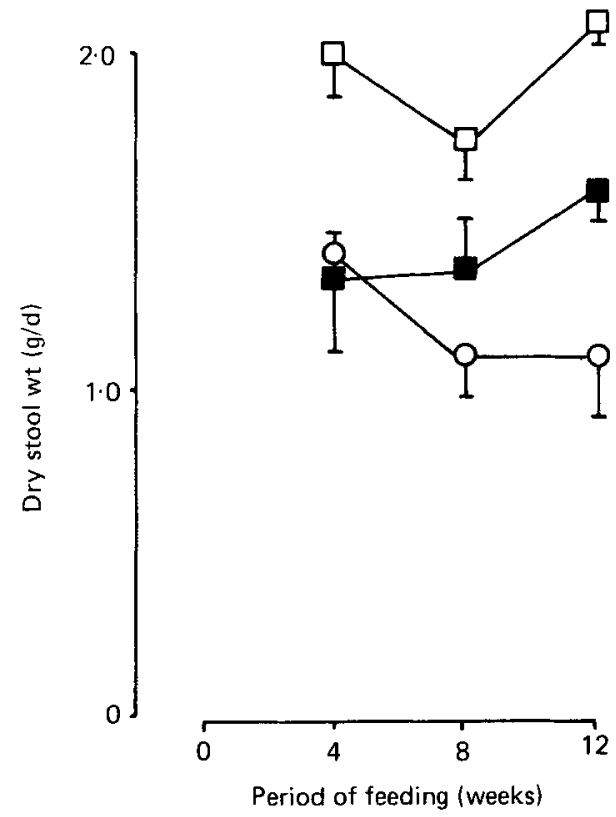

Fig. 1. Daily dry stool weight (g) of rats given the control diet $(O)$, control $+100 \mathrm{~g}$ gum arabic/kg ( $\square$ ), control $+100 \mathrm{~g}$ coarse wheat bran $/ \mathrm{kg}(\square)$. Points are mean values with their standard errors represented by vertical bars. Significant differences were observed between the diets $(P<0.01)$. Time-period was not a significant influence.

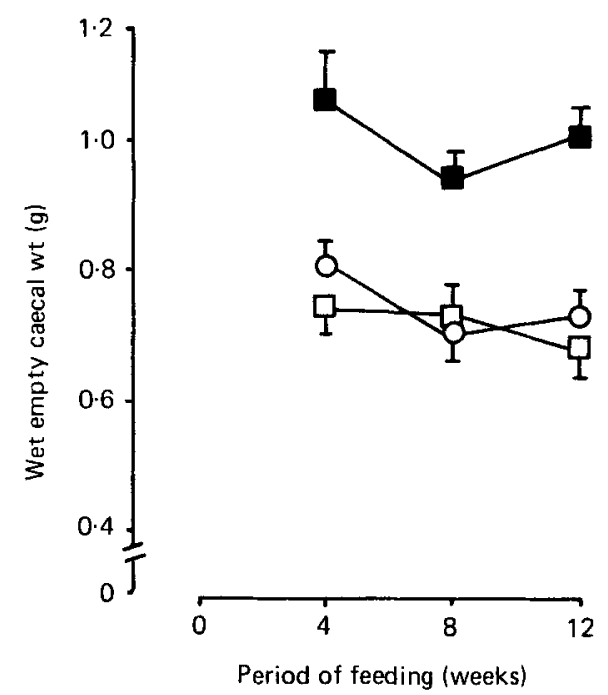

Fig. 2. Wet empty caecal weights of rats given the control diet $(\bigcirc)$, control $+100 \mathrm{~g}$ gum arabic/ $\mathrm{kg}(\boldsymbol{G})$ control $+\mathrm{l} 00 \mathrm{~g}$ coarse wheat bran $/ \mathrm{kg}(\square)$. Points are mean values with their standard errors represented by vertical bars. Significant differences were observed between the diets $(P<0.01)$. Time-period was not a significant factor. 


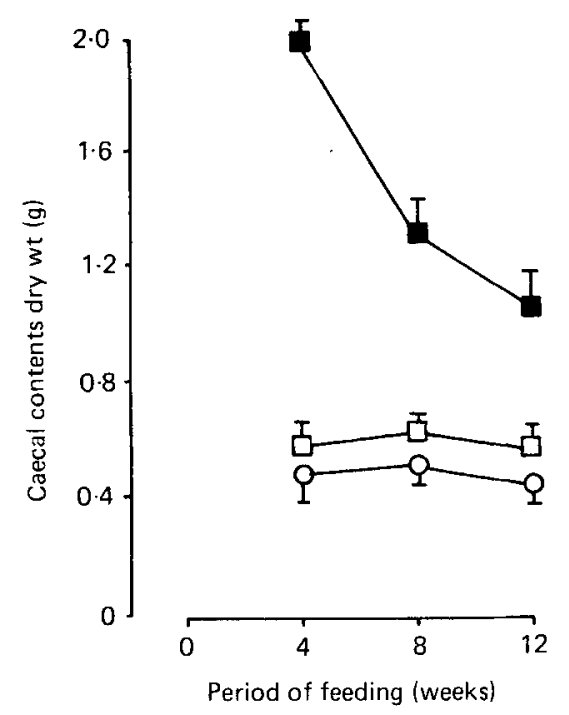

Fig. 3. Dry weight of caecal contents from rats given the control diet $(O)$, control $+100 \mathrm{~g}$ gum arabic $/ \mathrm{kg}$ (G), control $+100 \mathrm{~g}$ coarse wheat bran $/ \mathrm{kg}(\square)$. Points are mean values with their standard errors represented by vertical bars. A significant dietary interaction with time-period $(P<0.01)$ was observed.
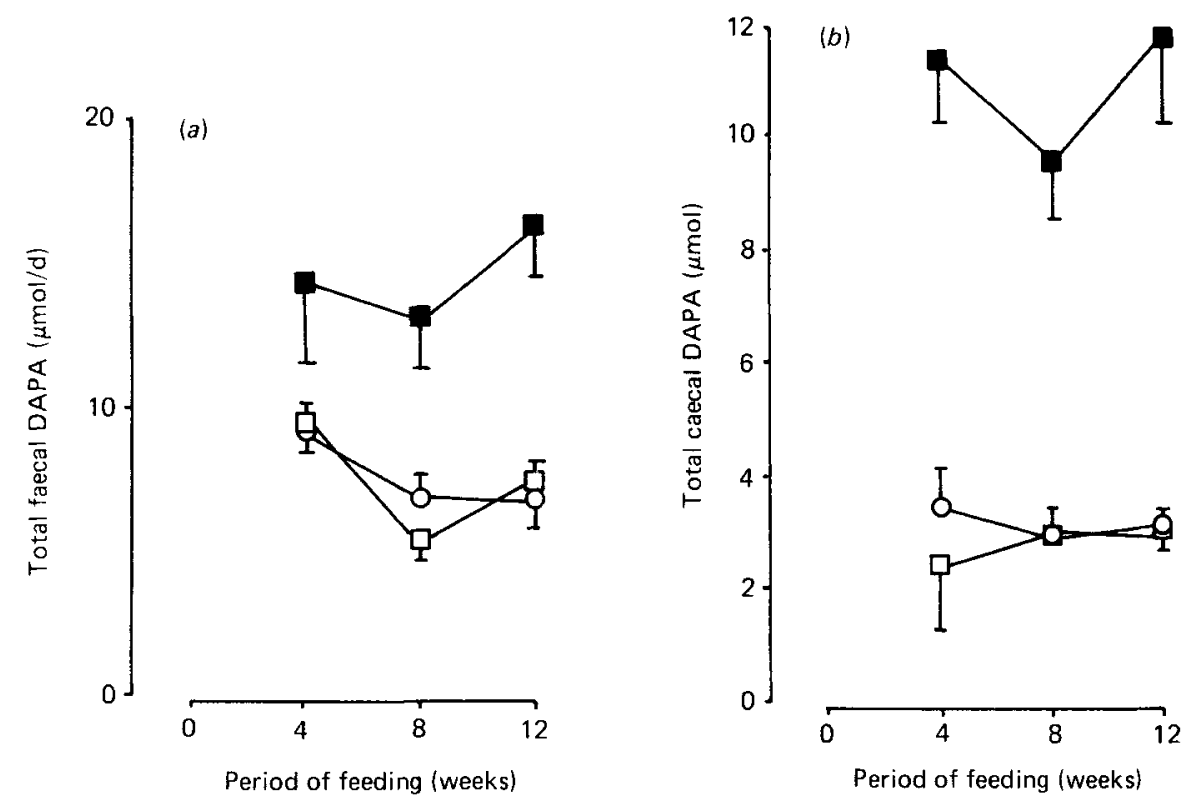

Fig. 4. Total $(a)$ faecal and $(b)$ caecal diaminopimelic acid (DAPA) from rats given the control diet $(O)$, control $+100 \mathrm{~g}$ gum arabic $/ \mathrm{kg}(\square)$, control $+100 \mathrm{~g}$ coarse wheat bran $/ \mathrm{kg}(\square)$. Points are mean values with their standard errors represented by vertical bars. Significant differences were noted between diets $(P<0.01)$. Time-period significantly influenced total faecal DAPA $(P<0.05)$.

$\mathrm{CH}_{4}$ was detected in all rats at 4 weeks (Table 3). For diet FF- and FG-fed rats this did not alter with time-period although no $\mathrm{CH}_{4}$ was detected from diet FB-fed rats at 8 weeks, and at 12-weeks there was a $60 \%$ decrease in $\mathrm{CH}_{4}$ production from diet $\mathrm{FG}$-fed rats compared with FG-fed rats at 8 weeks. The addition of $100 \mathrm{~g}$ coarse wheat bran $/ \mathrm{kg}$ significantly reduced absolute $\mathrm{CH}_{4}$ production in contrast to diet FF- and FG-fed rats. Diet 
Table 3. Hydrogen and methane production $(\mathrm{ml} / \mathrm{h}$ per $\mathrm{kg})$ in rats given a fibre-free diet $(F F)$ alone or supplemented with $100 \mathrm{~g} / \mathrm{kg}$ of either gum arabic (diet FG) or wheat bran (diet FB)

(Mean values with their standard errors for five rats/group except diet FG (8 weeks) where there were four rats/group)

\begin{tabular}{|c|c|c|c|c|c|c|c|c|c|}
\hline \multirow{2}{*}{$\begin{array}{l}\text { Period of feeding (weeks)... } \\
\text { Diet ... }\end{array}$} & \multicolumn{3}{|c|}{4} & \multicolumn{3}{|c|}{8} & \multicolumn{3}{|c|}{12} \\
\hline & $\mathrm{FF}$ & FG & FB & FF & FG & FB & FF & FG & FB \\
\hline \multicolumn{10}{|l|}{ Hydrogen } \\
\hline Mean & $0 \cdot 6$ & $0 \cdot 6$ & 0.7 & 0.5 & 0.7 & $0 \cdot 3$ & $0 \cdot 3$ & $0 \cdot 1$ & 0.4 \\
\hline SEM & $0 \cdot 3$ & $0 \cdot 1$ & 0.1 & $0 \cdot 1$ & $0 \cdot 2$ & $0 \cdot 1$ & $0 \cdot 1$ & $0 \cdot 1$ & $0 \cdot 1$ \\
\hline \multicolumn{10}{|l|}{ Methane } \\
\hline Mean & 0.6 & 0.9 & $0 \cdot 3$ & 0.9 & 0.7 & 0 & 0.5 & $0 \cdot 3$ & 0 \\
\hline SEM & 0.3 & $0 \cdot 3$ & $0 \cdot 3$ & 0.2 & 0.2 & - & $0 \cdot 1$ & 0.1 & - \\
\hline
\end{tabular}

significantly $(P<0 \cdot 01)$ influenced $\mathrm{CH}_{4}$ production (Table 3$) . \mathrm{CH}_{4}$ output showed no significant interaction between diet and time-period, nor was there a significant time-period effect (Tables 2 and 3).

Fig. $5(a$ and $b)$ shows caecal $(\mu \mathrm{mol})$ and faecal $(\mu \mathrm{mol} / \mathrm{d})$ total SCFA. Gum arabic caused a significant $(P<0.01)$ increase in total caecal SCFA relative to diet FF- and diet FB-fed rats. Time-period was not a significant factor. Total faecal SCFA were greatest on diet FG $(P<0 \cdot 01)$. There was no significant difference between diet FF- and diet FB-fed rats. Time-period was a significant influence $(P<0 \cdot 01)$, total faecal SCFA being stable after 8 weeks on any one diet (Table 2). Total faecal SCFA showed no significant interaction between diet and time-period, nor was there a significant time-period effect (Table 2).

Molar proportions of acetate, propionate and butyrate in dry caecal and faecal material are shown in Tables 4 and 5. Isobutyrate, isovalerate and valerate were not detected.

The addition of $100 \mathrm{~g}$ gum arabic/ $\mathrm{kg}$ increased caecal acetate (Table 4 ) by 24 and $6 \%$ $(P<0.01)$ relative to diets FB and FF respectively. In faecal material (Table 5), gum arabic caused a $10 \%$ decrease in molar proportion of acetate $(P<0.01)$ relative to diets $\mathrm{FB}$ and FF. There was no significant difference between diets FF and FG.

Diet did not affect the molar proportion of caecal propionate but the proportion decreased significantly to a stable value after 4 weeks (Table 4 ). The main difference in individual SCFA output between diet FG- and FF- and FB-fed rats was in faecal propionate excretion (Table 5).

Diet FG-fed rats excreted less acetate and more propionate $(P<0.01)$ than diet FF- or FB-fed groups. The modest indication of a dietary interaction with time-period $(P<0.01)$ may result from individual variation of rats given diet FB (range $0-27 \mathrm{mmol} / \mathrm{mol}$ ) and diet FF (range $0-123 \mathrm{mmol} / \mathrm{mol}$ ).

The molar proportion of caecal butyrate increased on diet FB $(P<0.01)$ (Table 4) compared with diet FF. The molar proportion of caecal butyrate decreased on diet FG relative to the value on diet FF. All were significantly different from each other. Diet significantly influenced caecal acetate and butyrate production $(P<0.01)$. Time-period significantly $(P<0.01)$ influenced propionate production (Table 2$)$.

For each of the individual SCFA in caecum and faeces no significant interaction between diet and time-period was shown, nor was there a significant time-period effect (Table 2).

Mean values of total caecal and faecal bile acids are given in Fig. 6. Gum arabic resulted in the highest total caecal bile acid content. Total faecal bile acid excretion was greatest with diet FB.

The total excretions of individual bile acids are given in Table 6 . With the exception of 

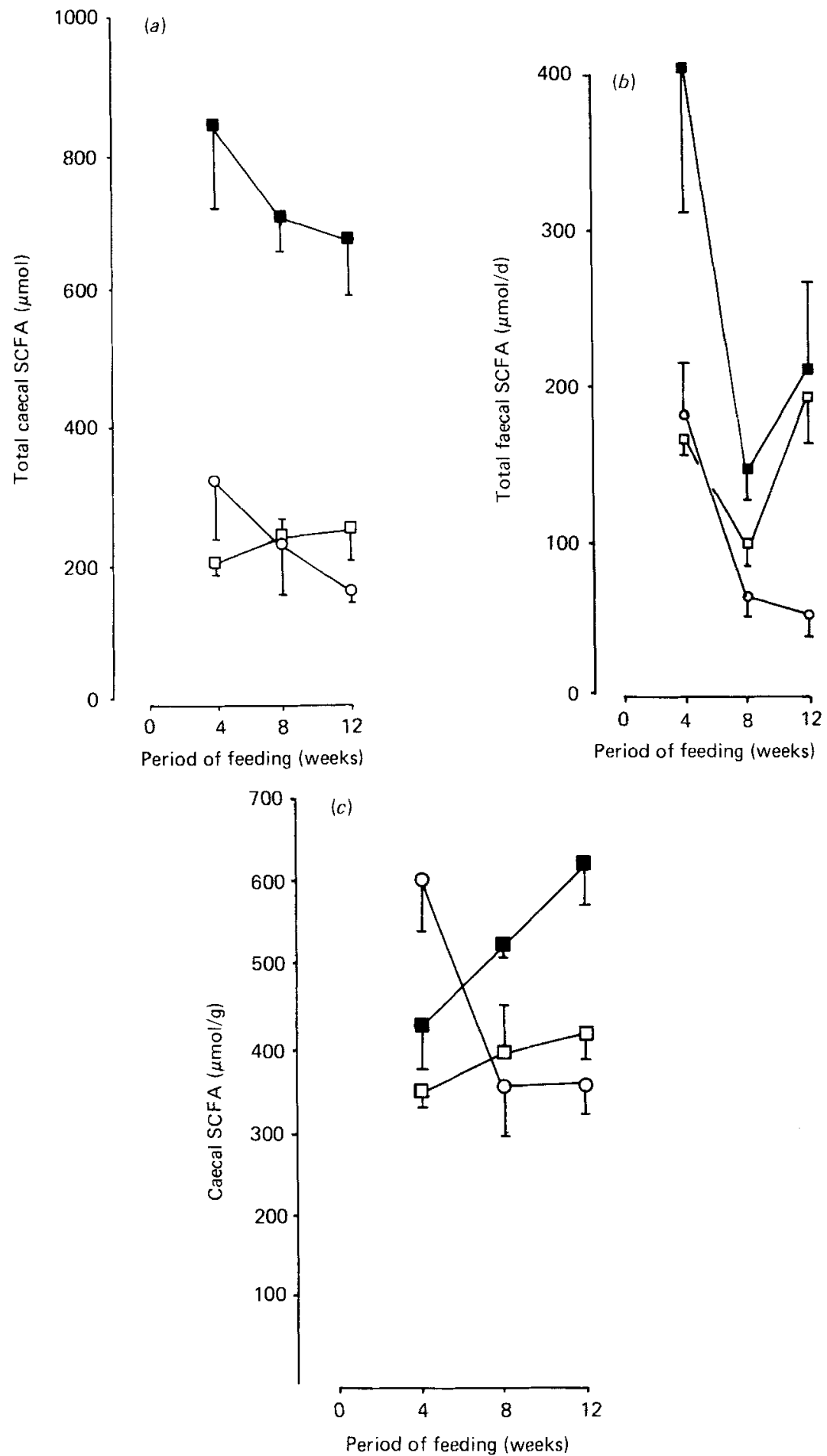

Fig. 5. Total short-chain fatty acids (SCFA) in (a) caecal and (b) faecal material, and (c) SCFA

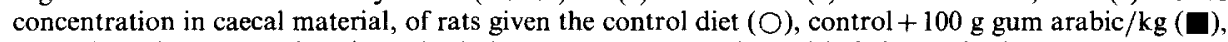
control $+100 \mathrm{~g}$ coarse wheat bran $/ \mathrm{kg}(\square)$. Points are mean values with their standard errors represented by vertical bars. Significant differences in total SCFA in caecal and faecal material were observed between the diets $(P<0.01)$. Time-period was a significant influence on faecal SCFA $(P<0.01)$. 
Table 4. Molar proportions ( $\mathrm{mmol} / \mathrm{mol}$ ) of short-chain fatty acids in dry caecal material in rats given a fibre-free diet $(F F)$ alone or supplemented with $100 \mathrm{~g} / \mathrm{kg}$ of either gum arabic (diet $F G)$ or wheat bran (diet $F B)$

(Mean values with their standard errors for five rats/group)

\begin{tabular}{|c|c|c|c|c|c|c|c|c|c|}
\hline \multirow{2}{*}{$\begin{array}{l}\text { Period of feeding (weeks)... } \\
\text { Diet... }\end{array}$} & \multicolumn{3}{|c|}{4} & \multicolumn{3}{|c|}{8} & \multicolumn{3}{|c|}{12} \\
\hline & $\mathrm{FF}$ & $\mathrm{FG}$ & FB & FF & $F G$ & FB & FF & FG & FB \\
\hline \multicolumn{10}{|l|}{ Acetate } \\
\hline Mean & 642 & 687 & 531 & 653 & 699 & 591 & 689 & 725 & 588 \\
\hline SEM & 24 & 26 & 15 & 20 & 48 & 9 & 15 & 88 & 13 \\
\hline \multicolumn{10}{|l|}{ Propionate } \\
\hline Mean & 193 & 217 & 208 & 186 & 190 & 160 & 165 & 165 & 164 \\
\hline SEM & 6 & 14 & 15 & 13 & 23 & 6 & 12 & 11 & 7 \\
\hline \multicolumn{10}{|l|}{ Butyrate } \\
\hline Mean & 130 & 88 & 254 & 151 & 107 & 219 & 145 & 106 & 237 \\
\hline SEM & 9 & 13 & 11 & 13 & 65 & 21 & 15 & 29 & 8 \\
\hline
\end{tabular}

Table 5. Molar proportions ( $\mathrm{mmol} / \mathrm{mol}$ ) of short-chain fatty acids in dry faecal material in rats given a fibre-free diet $(F F)$ alone or supplemented with $100 \mathrm{~g} / \mathrm{kg}$ of either gum arabic (diet $F G$ ) or wheat bran (diet $F B$ )

(Mean values with their standard errors for five rats/group except diet FG (8 weeks) where there were four rats/group)

\begin{tabular}{|c|c|c|c|c|c|c|c|c|c|}
\hline \multirow{2}{*}{$\begin{array}{l}\text { Period of feeding (weeks)... } \\
\text { Diet ... }\end{array}$} & \multicolumn{3}{|c|}{4} & \multicolumn{3}{|c|}{8} & \multicolumn{3}{|c|}{12} \\
\hline & $\mathrm{FF}$ & FG & FB & FF & FG & FB & FF & $\mathrm{FG}$ & FB \\
\hline \multicolumn{10}{|l|}{ Acetate } \\
\hline Mean & 902 & 848 & 936 & 942 & 793 & 974 & 1000 & 842 & 872 \\
\hline SEM & 35 & 27 & 27 & 36 & 28 & 26 & 0 & 44 & 55 \\
\hline \multicolumn{10}{|l|}{ Propionate } \\
\hline Mean & 54 & 114 & 0 & 24 & 137 & 0 & 0 & 120 & 63 \\
\hline SEM & 24 & 9 & - & 24 & 6 & - & - & 31 & 27 \\
\hline \multicolumn{10}{|l|}{ Butyrate } \\
\hline Mean & 43 & 37 & 64 & 0 & 71 & 26 & 0 & 37 & 64 \\
\hline SEM & 18 & 11 & 60 & - & 25 & 26 & -- & 23 & 29 \\
\hline
\end{tabular}

hyodeoxycholic acid, gum arabic caused the total amount of all individual bile acids to be increased. Gum arabic had little influence on faecal excretion of individual bile acids. Wheat bran had the greatest influence on faecal constituent bile acids with the exception of chenodeoxycholic ( 12 weeks), $\alpha$ - and $\beta$-muricholic ( 4 and 8 weeks), and $\omega$-muricholic ( 8 and 12 weeks) acids. The total concentrations of caecal and faecal bile acids are given in Fig. 6(a). There appeared to be no significant differences in the trends exhibited by diets FF and FB. The concentration of caecal bile acids was greatest with diet FG at both 4 and 12 weeks. There appeared to be little difference in the effect of diets FG and FB. All three diets were associated with an increase in faecal concentration at 8 weeks, total concentration being greatest with the wheat bran diet. There appeared to be little difference between the faecal concentration of bile acids from rats given diets FG and FF.

In caecal material there was little effect of duration of feeding on the total bile acids of diet FB- and diet FF-fed groups. Total bile acids decreased after 8 weeks with diet FG. 

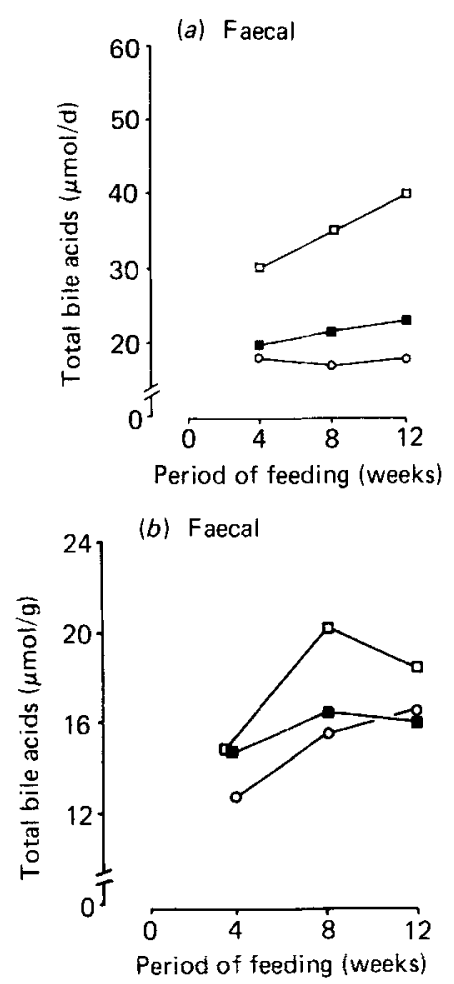
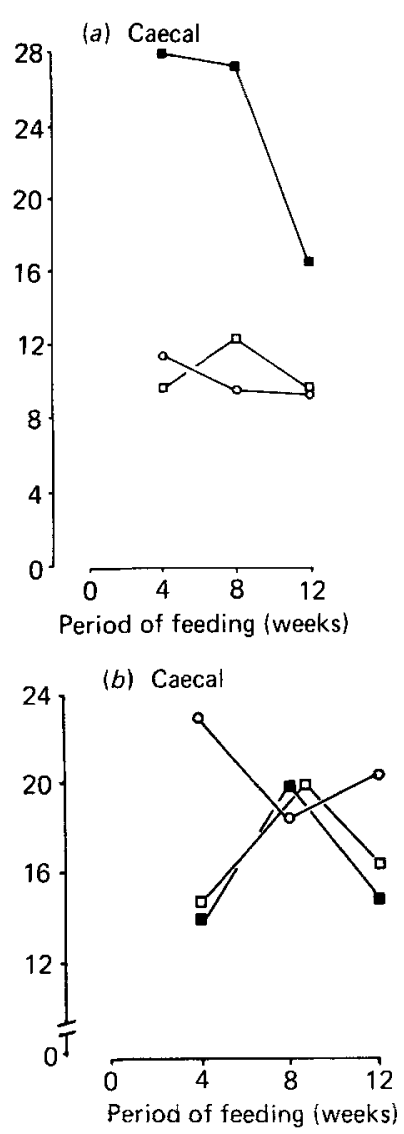

Fig. 6. (a) Mean total and (b) mean concentration of caecal and faecal bile acids of rats given the control $(\mathrm{O})$, control $+100 \mathrm{~g}$ gum arabic $/ \mathrm{kg}(\square)$, control $+100 \mathrm{~g}$ coarse wheat bran $/ \mathrm{kg}(\square)$. Points are mean values.

\section{DISCUSSION}

Time-period did not influence stool weight. Stool weight had equilibrated by 4 weeks with diet FB. After 8 weeks diet FG resulted in a slight increase in stool weight. After 4 weeks the stool weight of rats given diet FF had diminished slightly, reflecting the lack of fermentable substrate and bulk. A period of 4 weeks may be sufficient for the assessment of novel dietary fibre source in future trials. Bacterial mass, as measured by DAPA, appeared to have stabilized after 4 weeks, both in the caecal and faecal material.

As anticipated, the presence of wheat bran in the diet significantly increased dry stool weight (Williams \& Olmstedt, 1936; Eastwood et al. 1973; Cummings et al. 1978). The change in stool weight with the gum arabic diet was not significant. The increase in stool weight resulting from fibre has been suggested to be due to either increases in the colonic water-holding capacity (Eastwood et al. 1983) or increases in the colonic bacterial mass (Cummings, 1981). Stephen \& Cummings (1980) suggested that wheat bran increased faecal bulk by virtue of its water-holding capacity, whereas the faecal increase from vegetable fibre was due mainly to increased microbial growth. Total faecal DAPA was not altered by the presence of wheat bran, and concentration of DAPA was lowest with the wheat bran diet suggesting that in this instance bacterial mass was not a significant contributor to increased 
Table 6. Composition of bile acids (means) in pooled caecal $(C)$ and faecal $(F)$ contents and mean values for total bile acids in $F(\mu \mathrm{mol} / d)$ and $C$ contents $(\mu \mathrm{mol})$

(Pooled results for five rats in each measurement)

\begin{tabular}{|c|c|c|c|c|c|c|c|c|c|}
\hline \multirow{2}{*}{$\begin{array}{l}\text { Period of feeding (weeks)... } \\
\text { Diet ... }\end{array}$} & \multicolumn{3}{|c|}{4} & \multicolumn{3}{|c|}{8} & \multicolumn{3}{|c|}{12} \\
\hline & $\mathrm{FF}$ & FG & FB & $\mathrm{FF}$ & $\mathrm{FG}$ & FB & FF & $\mathrm{FG}$ & FB \\
\hline Total $\mathrm{F}$ bile acids $(\mu \mathrm{mol} / \mathrm{d})$ & $17 \cdot 8$ & $20 \cdot 1$ & $29 \cdot 9$ & $17 \cdot 3$ & $22 \cdot 2$ & $35 \cdot 5$ & $18 \cdot 2$ & $26 \cdot 0$ & $40 \cdot 0$ \\
\hline Total $\mathrm{C}$ bile acids $(\mu \mathrm{mol})$ & $10 \cdot 0$ & $27 \cdot 8$ & $9 \cdot 6$ & 9.6 & 26.9 & $12 \cdot 4$ & $9 \cdot 4$ & $16 \cdot 6$ & $9 \cdot 4$ \\
\hline \multicolumn{10}{|l|}{ Bile acids $(\mathrm{mmol} / \mathrm{mol})$} \\
\hline \multicolumn{10}{|l|}{ Cholic } \\
\hline $\mathrm{F}$ & 120 & 80 & 90 & 110 & 90 & 140 & 140 & 110 & 130 \\
\hline $\mathrm{C}$ & 200 & 80 & 150 & 140 & 130 & 130 & 150 & 100 & 100 \\
\hline \multicolumn{10}{|l|}{ Chenodeoxycholic } \\
\hline $\mathrm{F}$ & 60 & 60 & 50 & 50 & 50 & 30 & 40 & 70 & 40 \\
\hline $\mathrm{C}$ & 30 & 20 & 10 & 20 & 30 & 20 & 20 & 10 & 20 \\
\hline \multicolumn{10}{|l|}{ Deoxycholic } \\
\hline $\mathrm{F}$ & 190 & 180 & 160 & 210 & 170 & 140 & 170 & 160 & 170 \\
\hline $\mathrm{C}$ & 270 & 150 & 200 & 270 & 210 & 180 & 200 & 180 & 180 \\
\hline \multicolumn{10}{|l|}{ Lithocholic } \\
\hline $\mathrm{F}$ & 50 & 60 & 60 & 60 & 60 & 40 & 40 & 40 & 40 \\
\hline $\mathrm{C}$ & 30 & 40 & 60 & 30 & 40 & 50 & 20 & 40 & 40 \\
\hline \multicolumn{10}{|l|}{ Hyodeoxycholic } \\
\hline $\mathrm{F}$ & 370 & 210 & 400 & 400 & 280 & 500 & 450 & 320 & 450 \\
\hline $\mathrm{C}$ & 300 & 60 & 310 & 280 & 100 & 510 & 430 & 100 & 420 \\
\hline \multicolumn{10}{|l|}{$\alpha$-Muricholic } \\
\hline $\mathrm{F}$ & 20 & 50 & 30 & 20 & 40 & 0 & 20 & 0 & 20 \\
\hline C & 30 & 70 & 50 & 40 & 60 & 10 & 10 & 30 & 30 \\
\hline \multicolumn{10}{|l|}{$\omega$-Muricholic } \\
\hline $\mathrm{F}$ & 90 & 190 & 80 & 100 & 220 & 60 & 60 & 90 & 60 \\
\hline C & 132 & 290 & 120 & 110 & 200 & 40 & 80 & 160 & 90 \\
\hline \multicolumn{10}{|l|}{$\beta$-Muricholic } \\
\hline $\mathrm{F}$ & 100 & 180 & 130 & 50 & 100 & 80 & 70 & 200 & 100 \\
\hline $\mathrm{C}$ & 120 & 280 & 100 & 130 & 220 & 60 & 70 & 370 & 120 \\
\hline
\end{tabular}

stool weight. Fibre, such as wheat bran, may increase stool weight by water holding, but with little additional effect on caecal metabolism as suggested by $\mathrm{CH}_{4}$ and SCFA results.

Diet FG caused a significant increase in caecal-contents dry weight which exceeded stool output when feeding the same diet for 8 weeks, although after 12 weeks caecal weight had decreased to below stool weight. Wheat bran had none of these effects. Ryan et al. (1979) found that a high-fibre diet increased large-intestinal-contents weight. Dowling et al. (1967) gave rats kaolin for 9-12 months and found caecal dilatation in bulk-fed rats and increases in large-bowel-contents weight relative to control rats. Moinuddin \& Lee (1959) showed that the empty caecal sac as well as the dried contents were heavier in rats given potato starch as opposed to lactose, cellulose or maize-starch-fed animals; cellulose producing the lightest caecal sac and contents. Murray et al. (1980) found that hypertrophy of the large intestine occurred when rats were given a high-fibre diet.

The increases in caecal-contents weight described both in this present paper and previously could be due to a prolonged caecal residence following high-fibre diets and increased bacterial mass and metabolic products, the increased weight of contents causing caecal distension and hypertrophy or hyperplasia. Dowling et al. (1967) and McLean-Ross et al. (1984) found no macroscopic or histological evidence of caecal-wall hypertrophy, but only thickening of the muscle coat of the large bowel. In contrast, Younoszai et al. (1978) 
found that, compared with fibre-free diets, diets with fibre increased small intestinal and colonic, but not stomach or caecal growth.

DAPA can be found in nearly all bacteria except Streptomyces spp. and Actinomyces spp; it is found in blue-green algae but not in fungi, yeasts, plant viruses and protozoa (Work $\&$ Dewey, 1953). The presence of DAPA in the bacterial cell wall can be used as a marker of bacterial mass. However, the cell-wall DAPA content varies from species to species (Czerkawski, 1974).

Gum arabic supplementation significantly increased total faecal and caecal DAPA. The increase in faecal DAPA appeared to continue up to the last measurement at 12 weeks. Yet, with diet FG, caecal DAPA appeared to stabilize by week 4 . If the caecum directly affected faecal output then the process appears to have been slow and may not have been mediated through a mechanism which directly involved changes in bacterial mass. However, no information is available from these experiments for further speculation. There was no increase in caecal or faecal DAPA with diet FB. A fermented gum such as gum arabic is believed to increase stool weight by the proliferation of the bacterial mass (Stephen \& Cummings, 1980). The results of the present experiment showed a threefold increase in DAPA in the caecum with diet FG. The faecal DAPA increased by approximately $50 \%$ as did the faecal weight by the end of the 12 week feeding period. The increase in DAPA may represent an increased bacterial mass or an increase in bacteria with DAPA-rich cell walls. Diet FB must have mediated its effect on stool weight through a non-fermenting mechanism, presumably its water-holding capacity (Eastwood et al. 1983).

All $\mathrm{H}_{2}$ produced in man is assumed to be of bacterial origin in the colon (Levitt, 1969) and indicates caecal carbohydrate metabolism (Bond \& Levitt, 1978). Wheat bran is a relatively poor substrate for gas production by colonic bacteria (Nyman \& Asp, 1982). Dietary supplementation with a fermentable polysaccharide or carbohydrate increases the amount of $\mathrm{H}_{2}$ produced (Calloway, 1966; McKay \& Eastwood, 1983). McLean-Ross et al. (1984) showed no change in excreted $\mathrm{H}_{2}$ concentration in rats given a diet supplemented with gum arabic. When a low-residue diet was fed with the same supplement it was only after $28 \mathrm{~d}$ that $\mathrm{H}_{2}$ was produced.

Diet $\mathrm{FB}$ virtually abolished $\mathrm{CH}_{4}$ production $(P<0.01)$ with no significant difference between the effect of diets FG and FF. The abolition of $\mathrm{CH}_{4}$ excretion with the wheat-bran diet is similar to the findings of McKay \& Eastwood (1983). McLean-Ross et al. (1984), however, found that feeding an elemental diet for 3 weeks increased $\mathrm{CH}_{4}$ excretion and decreased $\mathrm{H}_{2}$ excretion. In the present study there were peaks with diet $\mathrm{FG}$ at 8 weeks, $\left(\mathrm{H}_{2}\right)$ thereafter declining, whilst $\mathrm{CH}_{4}$ peaked at 4 weeks, suggesting caecal fermentation of gum arabic. Wheat bran, which has a compressed structure, was not extensively degraded and could have been acting as an inhibitor to methanogens and subsequent $\mathrm{CH}_{4}$ production. In man there may be an association between diet and $\mathrm{CH}_{4}$ production but not equally affecting $\mathrm{H}_{2}$ and $\mathrm{CH}_{4}$ production (Tadesse et al. 1980).

The duration of feeding did not significantly affect $\mathrm{CH}_{4}$ production (except with diet $\mathrm{FB}$ ), whereas $\mathrm{H}_{2}$ excretion was affected by the time-period $(P<0.01)$ suggesting that bacterial metabolic adaptation to diet change occurred after 4 weeks but certainly by 8 weeks after a new dietary regimen.

Diet FB appeared to be associated with a diminished total faecal and total caecal DAPA and the abolition of $\mathrm{CH}_{4}$ excretion. However, this did not hold for diet FG. It is surprising that gum arabic supplementation resulted in no increase in $\mathrm{CH}_{4}$ production, especially as this supplementation was associated with fibre metabolism and an increased bacterial mass. From Table 3 it can be seen that $\mathrm{CH}_{4}$ production with diet $\mathrm{FG}$ actually decreased with time, although this decrease was not statistically significant.

SCFA are one of the major products of microbial fermentation of carbohydrate. Remesy 
\& Demigne (1976) demonstrated that SCFA are absorbed in the rat, contributing 4-7\% of the total energy requirement (Yang et al. 1970).

The increases in caecal SCFA on diet FG were to be expected as evidence of increased fermentation in association with an increased caecal weight and bacterial mass. This did not occur with diets FF and FB, an indication perhaps of a lack of available substrate. Caecal SCFA did not increase after 4 weeks yet the faecal SCFA stabilized after 8 weeks. Again, as with the DAPA results, the SCFA values show, as might be expected, that stabilization in the caecum occurred some time earlier than in the faecal output, in this case by more than 4 weeks but certainly by 8 weeks.

The faecal concentrations of SCFA were considerably less than those observed by Remesy \& Demigne (1976), although the results obtained from rats fed for 12 weeks were similar. It appears that although total stool output and total SCFA decreased with time, the two did not parallel each other sufficiently to maintain the concentration of SCFA in the stool.

Diet FG stimulated an increase in caecal acetate content in excess of that observed by McLean-Ross et al. (1984), who showed that adding gum arabic to two different diets increased the production of SCFA. This suggests that the diet to which gum arabic is added is important. The molar proportions of SCFA after giving the FB and FF diets corresponded with the results of McKay \& Eastwood (1983) and Remesy \& Demigne (1976).

Caecal propionate with all diets reduced with time-period. These results are again comparable with those of Remesy \& Demigne (1976).

Diet FB had little effect on acetic and propionic acids but was significantly associated with increased dry caecal and faecal butyrate contents compared with diet FG. The molar proportions in dry caecal contents on diet FG were similar to those of McKay \& Eastwood (1983) where rats were given a wheat bran and meat diet.

Cummings et al. (1979) found that neither the total faecal SCFA concentration nor relative proportions of individual SCFA were altered with diet and that this suggested colonic absorption. Spiller et al. (1980) found acetic acid to be the major acid when three different diets were given in human studies. However, they found little difference between the molar proportions of propionic and butyric acids. Our results indicate that diet affected the concentrations of acetate. There was an interaction between diet and duration of feeding on faecal propionate alone, whilst only time-period influenced caecal propionate levels and only diet significantly influenced caecal butyrate. Faecal acetate was significantly reduced with diet FG $(P<0.01)$. Propionate was of particular interest because of the effect of time-period interacting with diet. Diet FG increased the proportion of faecal propionate, although less than in the colon, whilst diet FB, having no effect after 4 and 8 weeks, caused a massive increase in faecal propionate after 12 weeks. It appears that there could have been a rate of production and absorption of propionate above which anything excess to requirements is excreted.

Dietary fibre can interact with bile acids and intestinal flora and alter the relative sizes and faecal excretion of various bile-salt pools (Story \& Kritchevsky, 1978). The extent to which fibre binds bile acids is characteristic for each fibre and substrate (Kritchevsky, 1978).

Total faecal bile acids were greatest with diet FB, contrasting with the reports of Eastwood et al. (1973) and McLean Baird et al. (1977) who found that wheat bran did not alter total bile acid excretion. The period of feeding was less in these latter experiments. The concentration $(\mu \mathrm{mol} / \mathrm{g})$ of the bile acids also altered with diet and duration of feeding. The caecal concentration of bile acids was greatest with diet FF, with little difference between any of the diets at 8 weeks. Faecal concentration was greatest with diet FB. There was no difference between the effects of diets FB and FF on faecal concentrations or diets FG and FF on caecal concentrations. Walters et al. (1975) reported that the concentrations of faecal bile acids were lower in humans given wheat bran compared with those given a 
bagasse diet, but the wheat bran had no effect on the daily output. Eastwood et al. (1973) showed that wheat bran increased human stool output and had a concomitant diluting effect on the faecal bile acids. Diet FB appeared to have little effect on bile acids within the caecum. The unchanged faecal excretion of bile acids from rats given diet FG compared with diet FF suggests that where there is extensive metabolism of the fibre source, there could be retention of bile acids within the enterohepatic circulation. There was no apparent increased bacterial degradation of primary bile acids to secondary bile acids. The proportions of the individual bile acids tended to be similar on all three diets. It also appears that whereas diet was an influencing factor, duration of feeding was not a constant effect: diet FG resulted in an increased total caecal bile acids content compared with diet FF and thereafter the amount decreased, indicative of a possible negative feedback system of bile acid levels within the enterohepatic circulation.

We have studied the effects of diet and time on specified indices of fibre metabolism in the male adult rat over a period of 12 weeks. It is apparent that both duration of feeding and diet had noticeable effects on all measurements made and that they were not indiscriminate in their effects. Stool weight and total caecal and faecal bacterial mass had stabilized by 4 weeks. Other indicators of fibre metabolism, i.e. $\mathrm{H}_{2}, \mathrm{CH}_{4}$ and SCFA production, took longer to adapt and were influenced by fibre source, as were colonic bile acids. We believe the experimental design described in the present paper is useful for studying fibre metabolism. For the initial assessment of novel fibres, we suggest a 4-week period for the stool-weight collections and related analysis and longer time intervals (8-12 weeks) for metabolic events.

This work was supported and funded by Vick International. Grateful thanks are due to Dorothy M. MacDonald for her expert technical assistance, and patience, with the analysis of all short-chain fatty acids and bile acids.

\section{REFERENCES}

Anderson, D. M. W., Hirst, E. \& Stoppard, J. F. (1966). Journal of the Chemical Society 35, 1959-1966.

Bond, J. H. \& Levitt, M. D. (1978). American Journal of Clinical Nutrition 31, S169-S174.

Brydon, W. G., Tadesse, K., McKay, L., Smith, D. \& Eastwood, M. A. (1979). Journal of Chromatography 172, $450-452$.

Calloway, D. H. (1966). Gastroentereology 57, 383-389.

Cummings, J. H. (1975). Gut 16, 323.

Cummings, J. H. (1981), Colon and Nutrition, Falk Symposium no. 32, pp. 91-103 [H. Kasper and H. Goebell, editors]. Lancaster: MTP Press Ltd.

Cummings, J. H., Hill, M. J., Jivraj, T., Houston, H., Branch, W. J. \& Jenkins, D. J. A. (1979). American Journal of Clinical Nutrition 32, 2086-2093.

Cummings, J. H., Southgate, D. A. T., Branch, W. J., Houston, H., Jenkins, D. J. A. \& James, W. P. T. (1978). Lancet i, 5-9.

Czerkwaski, J. W. (1974). Journal of the Science of Food and Agriculture 25, 45-55.

Dowling, R. H., Riecken, E. O., Laws, J. W. \& Booth, C. C. (1967). Clinical Science 32, 1-9.

Eastwood, M. A., Kirkpatrick, J. R., Mitchell, W. D., Bone, A. \& Hamilton, T. (1973). British Medical Journal 4, 392-394.

Eastwood, M. A., Robertson, J. A., Brydon, W. G. \& McDonald, D. (1983). British Journal of Nutrition 50, $539-547$

Edozien, J. C. \& Switzer, B. R. (1978). Journal of Nutrition 108, 282-290.

Elsenhans, B., Blume, R. \& Caspary, W. F. (1981). American Journal of Clinical Nutrition 34, 1837-1848.

Goldin. B. R. \& Gorbach, S. L. (1976). Journal of the National Cancer Institute 57, 371-375.

Janowitz, H. D. \& Grossman, M. I. (1949). American Journal of Physiology 158, 184-193.

Kritchevsky, D. (1978). Lipids 13, 982-985.

Leegwater, D. C., de Groot, A. P. \& van Kalmthout-Kuyper, M. (1974). Food \& Cosmetics Toxicology 12, 687-697.

Levitt, M. D. (1969). New England Journal of Medicine 281, 122-127.

McKay, L. F. \& Eastwood, M. A. (1983). British Journal of Nutrition 50, 679-684. 
McLean Baird, I., Walters, R. L., Davies, P. S., Hill, M. J., Drasar, B. S. \& Southgate, D. A. T. (1977). Metabolism 26, 117-128.

McLean-Ross, A. H., Brydon, W. G., Eastwood, M. A., Anderson, J. R. \& Anderson, D. M. W. (1983). American Journal of Clinical Nutrition 37, 368-375.

Mclean-Ross, A. H., Eastwood, M. A., Brydon, W. G., Busuttil, A. \& McKay, L. F. (1984). British Journal of Nutrition 51, 47-56.

McNeil, N. I., Cummings, J. H. \& James, W. P. T. (1977). Gut 19, 819-822.

Mallett, A. K., Rowland, I. R. \& Wise, A. (1984a). Nutrition and Cancer 6, 86-91.

Mallett, A. K., Wise, A. \& Rowland, I. R. (1984b). Food \& Cosmetics Toxicology 22, 415-418.

Moinuddin, J. F. \& Lee, H. W. T. (1959). American Journal of Physiology 197, 903-911.

Murray, D., Fleiszer, D., McArdle, A. H. \& Brown, R. A. (1980). Journal of Surgical Research 29, $135-140$.

Nyman, M. \& Asp, N. G. (1982). British Journal of Nutrition 47, 357-366.

Remesy, C. \& Demigne, C. (1976). Annales de Recherches Veterinaires 7, 39-55.

Rodkey, F. L., Collison, H. A. \& O'Neal, J. D. (1972). Journal of Applied Physiology 33, 256-260.

Royal College of Physicians (1980). Medical Aspects of Dietary Fibre, p. 3. London: Pitman Medical.

Ryan, G. P., Dudrick, S. J., Copeland, E. M. \& Johnson, L. R. (1979). Gastroenterology 77, $658-663$.

Spiller, G. A., Chernoff, M. C., Hill, R. A., Gates, J. E., Nassar, J. J. \& Shipley, E. A. (1980). American Journal of Clinical Nutrition 33, 754-759.

Stephen, A. M. \& Cummings, J. H. (1980). Nature 284, 283-284.

Story, J. A. \& Kritchevsky, D. (1978). American Journal of Clinical Nutrition 31, S199 S202.

Tadesse, K., Smith, A., Brydon, W. G. \& Eastwood, M. A. (1979). Journal of Chromatography 171, 416-418.

Tadesse, K., Smith, D. \& Eastwood, M. A. (1980). Quarterly Journal of Experimental Physiology 65, 85-97.

Thomsen, L. L., Tasman Jones, C., Lee, P. S. \& Robertson, A. M. (1981). Colon and Nutrition. Falk Symposium no. 32, pp. 47-53 [H. Kasper and H. Goebell, editors]. Lancaster: MTP Press Ltd.

Van Soest, P. J. (1966). Journal of the Association of Official Analytical Chemists 49, 546-566.

Walters, R. L., McLean Baird, I., Davies, P. S., Hill, M. J., Drassar, B. S., Southgate, D. A. T., Green, J. \& Moregan, J. (1975). British Medical Journal ii, 536-538.

Williams, R. D. \& Olmstedt, W. H. (1936). Journal of Nutrition 11, 433-449.

Work, E. \& Dewey, D. L. (1953). Journal of General Microbiology 9, $394-409$.

Yang, M. G., Manoharan, K. \& Mickelsen, V. (1970). Journal of Nutrition 100, 545-550.

Younoszai, M. K., Adedoyin, M. \& Ranshaw, J. (1978). Journal of Nutrition 108, 341-350. 